\title{
KRYZYS STREFY EURO I JEGO ŹRÓDŁA W FUNKCJONOWANIU PAŃSTWA OPIEKUŃCZEGO*
}

\section{WPROWADZENIE}

Żyjemy w czasach określanych przez wielu jako okres schyłku Zachodu. Jest to ocena $\mathrm{w}$ pewnej mierze słuszna, ale zdecydowanie fałszywe wydaja się powody, dla których taki zmierzch miałby nastąpić. Tak więc uważa się na przykład, że na szczyt światowej gospodarki dotarły nowe, dynamiczne kraje, które dość szybko zastąpią obecnych liderów: Stany Zjednoczone i Zachodnią Europę. Albo że do ruiny doprowadzili Zachód chciwi bankierzy (nowi szekspirowscy Shylockowie), a za ich ryzykanctwo i pazerność płaca teraz poczciwi obywatele, którzy w niczym nie przyczynili się do tej katastrofy, szlachetni zaś i współczujący politycy starają się tych poczciwców ratować przed katastrofa.

Pierwszy z wymienionych poglądów jest $\mathrm{z}$ gruntu błędny i traktuje wzrost gospodarczy w sposób, w jaki traktuje się rozwój niemowlęcia. Jeśli dziś niemowlę liczy $62 \mathrm{~cm}$ wzrostu i rośnie w tempie $1 \mathrm{~cm}$ miesięcznie, to w wieku 30 lat będzie liczyć ok. $6 \mathrm{~m}$ wzrostu. Gospodarki nie tylko rosną, ale i zmieniają swą strukturę, a niektóre zmiany strukturalne bywają bardzo trudne. Ponadto, każdy kraj ma swoje indywidualne problemy, które utrudniają mu dołączenie do najbogatszych krajów świata.

Co do drugiego $\mathrm{z}$ wymienionych poglądów, to oczywiście można podziwiać zręczność polityków zachodnich, którzy z okrzykiem: „łap złodzieja!” przerzucili odpowiedzialność na owych chciwych bankierów. Tymczasem obecny kryzys jest zawiniony przede wszystkim, i to w przytłaczającej mierze, przez polityków ${ }^{1}$.

Źródła kryzysu są więc - po pierwsze - wewnętrzne, po drugie - polityczne, i po trzecie - odwracalne. Ponieważ Europa Zachodnia jest, moim zdaniem, w znacznie trudniejszej sytuacji niż Stany Zjednoczone, więc swoją prezentację poświęciłem Europie. W pierwszej części zajmę się najbardziej palącym problemem, którym jest, na krótką metę, kwestia kryzysu Eurostrefy. Niemniej podkreślam, iż kryzys ten rozwiązany zostałby szybko i względnie niewielkim

\footnotetext{
* Referat przedstawiony w czasie konferencji „Współczesne wyzwania polityki finansowej”, zorganizowanej przez Katedrę Teorii Pieniądza i Polityki Pieniężnej Uniwersytetu Ekonomicznego w Poznaniu, 20 października 2011 r.

1 J. Winiecki, Aberracje w gospodarce? Szukajcie państwa!, w: idem (red.), Kryzys globalny. Poczatek czy koniec?, Regan Press, Gdańsk 2009, s. 145-161; idem, Global Financial Crisis: Where Are We Now and Where Are We Going - If Anywhere, „Bezpieczny Bank” 2010, nr 2, s. 35-46.
} 
kosztem, gdyby nie długookresowy kryzys ekonomiczny i społeczny europejskiego modelu państwa opiekuńczego, który podnosi koszt działań krótkookresowych i bardzo znacznie redukuje pole manewru polityki gospodarczej. Dlatego w drugiej części prezentacji zajmę się długookresowymi determinantami obecnego stanu krajów regionu, i wnioskami, jakie płyna z tej analizy.

\section{KRYZYS DZIWNEGO TWORU, CZYLI STREFY EURO}

\section{Jak tworzono strefę euro}

Na początku rozważań warto odnotować, że Europejską Unię Monetarną tworzono $\mathrm{w}$ innej kolejności niż to teoretycznie rozważano $\mathrm{w}$ podręcznikach o integracji gospodarczej. W literaturze przedmiotu przewiduje się bowiem wcześniejszą integrację polityki fiskalnej albo przynajmniej zharmonizowanie tej polityki przez wszystkich członków ugrupowania integracyjnego. Unia monetarna jest bowiem uważana za zwieńczenie długiego procesu integracji. Budowniczowie strefy euro uznali jednak za wystarczające, aby stworzyć regulacje specjalne (zawarte w Pakcie Stabilizacji i Wzrostu - PSW), mające dyscyplinować państwa członkowskie tworzącej się unii monetarnej.

Tyle rozwiązań instytucjonalnych. Praktyka w ramach tych rozwiązań była jeszcze gorsza. Wystarczą dwa przykłady. Po pierwsze, bardzo rygorystyczne reguły stworzone dla przyszłych przyjmowanych członków nie zostały zastosowane do „,starych” państw członkowskich UE tworzących strefę euro. Belgia, Włochy, a z niewielkim opóźnieniem także i Grecja, zostały członkami,

\section{Tabela 1}

Rejestr przekroczeń kryteriów Paktu Stabilizacji i Rozwoju przez państwa strefy euro przed kryzysem (2000-2007)

\begin{tabular}{|l|c|c|c|c|}
\hline \multicolumn{1}{|c|}{ Kraj } & $\begin{array}{c}\text { Przeciętna } \\
\text { wysokość } \\
\text { deficytu } \\
\text { (w \% PKB) }\end{array}$ & $\begin{array}{c}\text { Liczba lat } \\
\text { z deficytem } \\
\text { powyżej } \\
\text { pułapu }\end{array}$ & $\begin{array}{c}\text { Przeciętna } \\
\text { wysokość } \\
\text { długu } \\
\text { publicznego, } \\
\text { (w \% PKB) }\end{array}$ & $\begin{array}{c}\text { Liczba lat } \\
\text { z długiem } \\
\text { publicznym } \\
\text { powyżej } \\
\mathbf{6 0 \%} \text { PKB }\end{array}$ \\
\hline Niemcy & $-2,2$ & 4 & 63,6 & 7 \\
Austria & $-1,5$ & 1 & 64,5 & 6 \\
Belgia & $-0,3$ & 0 & 96,9 & 8 \\
Hiszpania & 0,3 & 0 & 47,6 & 0 \\
Finlandia & 4,1 & 0 & 41,6 & 0 \\
Francja & $-2,7$ & 3 & 61,8 & 5 \\
Grecja & $-5,0$ & 8 & 99,8 & 8 \\
Holandia & $-0,6$ & 1 & 50,5 & 0 \\
Irlandia & 1,5 & 0 & 30,5 & 0 \\
Włochy & $-2,9$ & 5 & 106,0 & 8 \\
Luksemburg & 2,3 & 0 & 6,3 & 0 \\
Portugalia & $-3,6$ & 4 & 58,3 & 3 \\
\hline
\end{tabular}

Źródło: La Caixa. Monthly Report, 2010. 
mimo iż nie spełniały kryterium relatywnego poziomu długu publicznego do PKB. Przy pułapie określonym $\mathrm{w}$ kryteriach $\mathrm{z}$ Maastricht, równym $60 \%$ krajowego PKB, wymienione trzy kraje przekraczały ten pułap o $40 \mathrm{i}$ więcej punktów procentowych.

Ale najgorsze miało dopiero nadejść. W połowie ubiegłej dekady Niemcy i Francja, nieznacznie przekroczając pułap deficytu budżetowego (4-5\% zamiast przewidzianego w kryteriach $3 \%$ PKB lub poniżej), zdecydowały się ,,rozmiękczyć" te kryteria, zamiast dokonać - niewielkich przecież - cięć wydatków publicznych. Szybko znalazły sojuszników i uchwaliły zmiany w regułach, które uczyniły PSW stworem niemal bezzębnym. Stworzyło to powszechne wrażenie, że nie obowiązują ż a d n e reguły. Niektóre kraje postanowiły z tego skorzystać. Rejestr przekroczeń reguł Paktu Stabilizacji i Wzrostu przez państwa członkowskie strefy euro przedstawia tabela 1 .

Obecna sytuacja jest zbyt znana, by się nią zajmować. Nie będę też wchodzić w spory, które z rozwiązań jest lepsze: mieć Grecję poza strefą euro czy wewnątrz, ale po odpowiedniej pokucie. Tutaj czytelnik może po prostu prześledzić doniesienia mediów.

\section{Klub bez reguł wyjścia}

Warto podkreślić jeszcze jedną szczególną cechę klubu nazwanego strefą euro. Otóż jest to klub, który ma bardzo wyśrubowane wymagania członkostwa, słabo zaś - jak wynika z doświadczeń niedawnej przeszłości - dyscyplinuje swych członków, którzy już się w klubie znajduja, a w dodatku nie określił w ogóle reguł wyjścia. Czyli nie ma przewidzianych procedur, które pozwoliłyby wykluczyć kraj członkowski, którego zachowanie odbiega od przyjętych reguł.

Autor niniejszej prezentacji ma wrażenie, że jest to sytuacja doskonale opisana w esejach filozoficznych Leszka Kołakowskiego, zatytułowanych Rozmowy $z$ diabtem. Jedno z opowiadań owego filozofa dotyczyło sytuacji, w której ktoś dostał się do nieba i tam właśnie się zbiesił. Problem filozoficzny był następujący: czy można wydalić z nieba kogoś, kto boskim wyrokiem został uznany za osobę godną niebiańskiej przyszłości? Przecież taka decyzja oznaczać musi podważenie zasady, że Bóg jest nie tylko wszechmogacy, ale także wszechwiedzący - a więc nie może się omylić!... Z czymś podobnym mamy do czynienia teraz w Europie. Oto możni strefy euro zdecydowali się stworzyć instytucję, która istnieć będzie po wieki wieków...

\section{Przyszłość strefy euro czy różne możliwe scenariusze przyszłości strefy euro?}

Trwają więc kolejne debaty polityczne, proponowane są kolejne rozwiązania, które następnie w wyniku niekorzystnych reakcji zewnętrznych sa zastępowane lub modyfikowane, a kryzys zatacza coraz szersze kręgi. Rynki finansowe są coraz bardziej zaniepokojone, a politycy i społeczeństwa - zwłaszcza w krajach o wyższym poziomie dyscypliny finansowej - coraz bardziej niechętne. W rezultacie analitycy zaczynaja myśleć o czymś, co jeszcze rok czy dwa lata temu wydawało się nie do pomyślenia. 
I rzeczywiście, rozważań o rozpadzie strefy euro się nie słyszało. Tymczasem obecnie, w jednym tygodniu, i to w jednym dzienniku (londyński „Financial Times"), przeczytałem dwie propozycje, z których każda sugerowała radykalna zmianę w kształcie strefy i w jej stanie członkowskim.

Pierwsza propozycja dotyczyła przekształcenia Europejskiego Funduszu Stabilności (EFS) w bank mający prawo sprzedaży obligacji europejskich. Autor sugerował, by nie przejmować się Niemcami, ich zastrzeżeniami ani też podobnymi reakcjami innych nacji (Holendrów, Finów, Austriaków) i stworzyć grupę krajów, która takie rozwiązanie akceptuje. Autor pominął jednak kwestię realizmu propozycji, czyli pytanie, jak wysoko oprocentowane musiałyby być owe obligacje grupy pozbawionej najsolidniejszych krajów strefy euro, aby znalazły one nabywców na rynkach finansowych. Chodzi o sama propozycje sugerująca wyprowadzenie poza strefę euro jej bardziej zdyscyplinowanych członków.

Ale nie koniec na tym. Parę dni później pojawił się w „Financial Times” artykuł niemieckiego przemysłowca, który stwierdził, co następuje. Skoro udała się trudna operacja stworzenia jednej waluty z siedemnastu krajowych walut, to na pewno mniejszym kosztem udałoby się stworzenie z jednej waluty - dwóch. Osobiście tę drugą koncepcję uważam za bardziej realistyczną niż tę pierwszą.

Wydaje się dość prawdopodobne, że ,,pęknięcie” w strefie euro w kwestiach walutowych może zaowocować podziałem na dwie strefy walutowe. Jedna tworzyliby zwolennicy silnej dyscypliny fiskalnej (i monetarnej zreszta też), a druga ,majsterkowicze”, czyli kraje, w których ingerencje polityki w kwestie fiskalne (i inne zresztą też...) wydają się raczej regułą niż wyjątkiem.

\section{REALNE PROBLEMY TKWIĄ GDZIE INDZIEJ, CZYLI EUROPA PRZYTŁOCZONA GÓRĄ WYDATKÓW SOCJALNYCH}

\section{Co zostaje po odrzuceniu fałszywego tropu?}

Napisałem we wprowadzeniu, że kryzys grecki pozostawałby na dalszych stronach czasopism gospodarczych, jako zjawisko peryferyjne dla gospodarki europejskiej czy światowej, gdyby nie bagaż obciążeń zachodnioeuropejskich gospodarek. I tak jest $\mathrm{w}$ istocie. Tutaj sformułowałbym nawet dalej idąca tezę, że tak zwany wielki globalny kryzys finansowy również byłby nieporównanie łatwiejszy do opanowania, gdyby kraje zachodnie nie uginały się tak dalece pod ciężarem długu publicznego, iż każde dalsze znaczne wydatki publiczne nadwyrężają i tak już raczej nie najwyższą wiarygodność kredytową tych krajów.

Kraje zachodnie znajduja się od dawna w pogarszającej się sytuacji gospodarczej i kryzys finansowy nie spowodował żadnego zwrotu w tej sytuacji. Przyspieszył jedynie trwający od dziesięcioleci proces słabnięcia dynamiki gospodarczej, wynikający z kumulacji problemów stwarzanych przez państwo opiekuńcze. To właśnie rosnące wydatki publiczne, w większej części na funkcjonowanie rozszerzającego się przez dziesięciolecia państwa opiekuń- 
czego, redukują bodźce do pracy, zarabiania, oszczędzania i inwestowania. A w konsekwencji ograniczają coraz bardziej możliwości wzrostu gospodarczego.

Wzrost ten doszedł do obecnego tempa rzędu 1,0-1,5\% rocznie, mimo iż niektóre państwa, próbując stymulować gospodarkę, wydawały pieniądze jak pijany marynarz po przybiciu do lądu. Stymulacje te niewiele - o ile w ogóle - pomagaja wzrostowi gospodarczemu, natomiast pogarszają równowage wewnętrzną i zewnętrzną gospodarki (zwiększając przy tym dług publiczny). Dodam, że porównanie zachowań państw z owym marynarzem jest niezbyt sprawiedliwe dla marynarza, który pija zwykle za swoje pieniądze, a nie za pożyczone...

Dlatego, odrzuciwszy łatwe slogany o chciwych bankowcach, spekulantach i innych rzekomych sprawcach obecnych problemów świata zachodniego, wydaje się rzeczą konieczną przyjrzenie się długookresowym tendencjom w zakresie wydatków publicznych i związkom tychże ze wzrostem gospodarczym i jego perspektywami. Autor niniejszej prezentacji uważa bowiem, że perspektywy te obciążone są na tyle silnie konsekwencjami przeszłości, że obecny bardzo wolny wzrost gospodarczy nie jest bynajmniej aberracja, która zniknie w następstwie monetarnej i fiskalnej ekspansji. Wydaje się nowa „,normą” dla tempa wzrostu PKB, której zmiana zależeć będzie nie od rozmaitych stymulacji, ale od skuteczności odwrócenia trendu rosnącego udziału państwa w podziale tworzonego bogactwa.

A to oznacza poważne cięcia w wydatkach państwa opiekuńczego. Wydatki bieżące i zobowiązania wobec przyszłych emerytów już obecnie znacznie przekraczają możliwości krajów zachodnich wytwarzania bogactwa. Cięcia te w niektórych krajach będą bolesne, ale niestety już nieuniknione.

Kiedy rozmawiam na te tematy w różnych środowiskach, często padaja pytania, jak to się stało, że nie było sygnałów ostrzegawczych, że wcześniej jakoś starczało tych pieniędzy. Otóż sygnały ostrzegawcze były i nieraz analitycy ostrzegali przed nadchodzącym kryzysem, ale byli zakrzykiwani przez chór obrońców państwa opiekuńczego, że to aspołeczne, że nieuzasadnione czarnowidztwo, że należy bogatych cisnąć jeszcze bardziej, by zapewnić pieniądze na „niezbędny socjal” (to samo słyszymy zresztą obecnie!). Natomiast powody, dla których udawało się tak długo unikać bankructwa państwa opiekuńczego, sa bardziej złożone.

Po pierwsze, powojenna ekspansja gospodarcza na Zachodzie dała politykom przeświadczenie o niemal nieograniczonych możliwościach. Na rynek pracy w latach 50. i 60. XX w. wchodziły znacznie liczniejsze roczniki niż zeń odchodziły na emeryturę czy rentę. Pieniędzy ze składek ubezpieczeniowych było więc dużo i politycy mogli dzięki temu okazywać się dobrymi wujkami, podwyższając poziom emerytur znacznie powyżej tego, który wynikałby z wysokości składek wnoszonych przez okres pracy zawodowej osób przechodzących na emeryturę. Nie oznaczało to wó w c z as naruszenia równowagi między wpływami ze składek a wydatkami systemu ubezpieczeń.

Ale proporcje demograficzne stopniowo ulegały niekorzystnym zmianom i politycy w latach 60., które były także latami ideologicznej ekspansji idei kolektywistycznych, zaczęli dorzucać coraz więcej pieniędzy na wydatki 
socjalne z kolejnego źródła, którym były coraz wyższe podatki. Tak więc w krajach OECD relacja wydatków publicznych do PKB (w skrócie: WP/PKB) zaczęła rosnąć: z $29 \%$ w latach 60 ., do $37 \%$ - w 70., $47 \%$ - w 80 . i do $50 \%$ w latach 90. XX w. Podatki, rzecz oczywista, rosły w podobnym tempie. Dodajmy też, że w Europie Zachodniej te relacje były z reguły jeszcze wyższe niż w szerszym gronie krajów OECD.

Niemiecki ekonomista Bernhard Heitger z Kilońskiego Instytutu Gospodarki Światowej podjął próbę znalezienia zależności między wzrostem relacji WP/PKB a spadkiem dynamiki wzrostu gospodarczego ${ }^{2}$. Niektóre szczegóły jego badań przynosi tabela 2. Obliczył on, że wzrost udziału wydatków publicznych o 10 punktów procentowych owocuje w okresie dekady spadkiem tempa wzrostu PKB o 0,5\%.

Nowsze studia potwierdzają negatywne relacje między poziomem podatków i wydatków publicznych a dynamiką PKB. Dwóch ekonomistów z Europejskiego Banku Centralnego, Antonio Afonso i Davide Furceri ${ }^{3}$, skalkulowało nawet wyższe efekty wzrostu podatków i wydatków publicznych, sięgające 1,2-1,3\% spadku rocznego tempa wzrostu PKB. Podobnie Andreas Bergh i Magnus Henrekson wskazuja w swoich badaniach na negatywny wpływ zarówno podatków, jak i wydatków publicznych, które obniżają tempo wzrostu PKB w granicach $0,9-1,1 \%$ rocznie ${ }^{4}$.

W książce na temat badanych zależności przedstawiają oni dalsze źródła empiryczne wspierające postawioną tezę o negatywnym wpływie podatków i wydatków publicznych na wzrost gospodarczy. Ich teza ogólna w cytowanej książce brzmi następująco: w odniesieniu do krajów bogatych, istnieją dowody empiryczne wspierające tezę o ,znaczącej negatywnej korelacji między ogólnym wzrostem wielkości rządu [to znaczy wysokością podatków i wydatków publicznych - J.W.] a wzrostem, gospodarczym. Przy tym związki przyczynowo-skutkowe biegną od wysokich podatków i wydatków publicznych do coraz niższego tempa wzrostu gospodarczego" ${ }^{5}$.

Wyniki powyższych badań potwierdzaja - warto przypomnieć - pesymistyczne poglądy Ludwiga Erharda, ojca powojennego niemieckiego „cudu gospodarczego". Erhard, obserwujac szybki wzrost redystrybucji w zachodnich Niemczech, już w 1964 r. stwierdził, że system oparty na zasadzie ,życia z ręką w kieszeni sąsiada” nie może przynieść dobrych efektów gospodarczych w dłuższym okresie.

Warto zasygnalizować, że tendencja przedstawiona w tabeli 2 ma daleko idące implikacje dla polityki makroekonomicznej. Jeśli niższe niż w poprzednim okresie tempo wzrostu PKB bierze się z osłabienia bodźców do pracy, zarabiania, oszczędzania i inwestowania, a w efekcie stanowi nową średnią

\footnotetext{
${ }^{2}$ The Scope of Government and Its Impact on Economic Growth in OECD Countries, Kiel Institute for Word Economics, Working Paper, nr 1034, 2001.

${ }^{3}$ Government Size, Composition, Volatility and Economic Growth, ECB Working Paper Series, nr 849, 2008.

${ }^{4}$ Government Size and Growth: Accounting for Economic Freedom and Globalization, 2010, „Public Choice", nr 142(1-2), 2010.

${ }^{5}$ A. Bergh, M. Henrekson, Government Size and Implications for Economic Growth, American Enterprise Institute, Washington, D.C., 2010.
} 


\section{Tabela 2}

Przeciętne dekadowe relacje WP/PKB oaz przeciętne dekadowe tempo wzrostu PKB per capita w krajach OECD w latach 1960-2000 (\%)

\begin{tabular}{|l|c|c|c|c|}
\hline \multicolumn{1}{|c|}{ Kraj/grupa krajów } & Lata $\mathbf{6 0 .}$ & Lata $\mathbf{7 0 .}$ & Lata $\mathbf{8 0 .}$ & Lata 90. \\
\hline Relacje WP/PKB & & & & \\
Belgia & & & & \\
Francja & 37,8 & 50,1 & 58,8 & 53,9 \\
Niemcy & 38,3 & 42,1 & 50,6 & 53,7 \\
Włochy & 37,0 & 45,6 & 47,6 & 50,5 \\
Luksemburg & 32,8 & 41,3 & 50,3 & 54,4 \\
Holandia & 33,7 & 45,6 & 54,0 &,, \\
Austria & 39,2 & 41,3 & 61,0 & 57,1 \\
Wielka Brytania & 38,5 & 45,4 & 50,5 & 53,3 \\
Hiszpania & 36,4 & 42,9 & 44,6 & 44,5 \\
Szwecja & 20,6 & 26,4 & 40,1 & 46,1 \\
USA & 37,7 & 52,4 & 62,8 & 62,8 \\
& 28,9 & 31,9 & 35,7 & 35,7 \\
OECD (średnia) & & & & \\
Tempo wzrostu & $\mathbf{2 9 , 4}$ & $\mathbf{3 7 , 5}$ & $\mathbf{4 4 , 5}$ & $\mathbf{4 6 , 3}$ \\
PKB per capita & & & & \\
Belgia & & & & \\
Francja & & & \\
Niemcy & 4,4 & 2,2 & 1,3 & 1,5 \\
Włochy & 4,7 & 2,2 & 1,2 & 1,0 \\
Luksemburg & 4,2 & 2,5 & 0,8 & 1,7 \\
Holandia & 5,6 & 3,3 & 1,4 & 1,1 \\
Austria & 3,0 & 1,1 & 2,9 & 1,8 \\
Wielka Brytania & 4,0 & 1,4 & 0,7 & 1,2 \\
Hiszpania & 5,2 & 2,7 & 1,3 & 0,7 \\
Szwecja & 2,3 & 1,4 & 2,3 & 1,4 \\
USA & 7,0 & 2,6 & 2,1 & 1,8 \\
OECD (średnia) & 2,9 & 0,7 & 1,3 & 2,4 \\
& 2,2 & 0,4 & 1,5 & 1,2 \\
& $\mathbf{4 , 0}$ & $\mathbf{2 , 0}$ & $\mathbf{1 , 7}$ & $\mathbf{1 , 5}$ \\
\hline
\end{tabular}

Źródło: B. Heitger, op. cit.

(przy danej strukturze bodźców), to polityka makroekonomiczna - stymulacyjna czy restrykcyjna - ma wpływ głównie na fluktuacje wokół tego nowego, niższego średniego tempa wzrostu PKB.

Stąd na przykład wyobrażenia amerykańskiej administracji, że tak zwany pakiet stymulacyjny prezydenta Obamy mógł trwale przesunąć gospodarkę amerykańską na poprzednią, wyższą trajektorię wzrostu gospodarczego, były iluzją. Bez równie trwałych zmian w strukturze bodźców jest to niemożliwe. Ale wróćmy do najważniejszego analizowanego w tej części prezentacji zagadnienia, czyli do kwestii finansowania niekończącej się ekspansji państwa opiekuńczego. 


\section{Jak sfinansować ciagle rosnące państwo opiekuńcze}

Moim zdaniem, można mówić o trzech-czterech fazach finansowania po II wojnie światowej. W pierwszej części zasygnalizowałem już pierwsze dwie fazy. A więc najpierw były to wysokie nadwyżki wpływów nad wydatkami w systemie ubezpieczeń społecznych. Wynikały one z faktu, że wchodzących na rynek pracy - i płacących składki ubezpieczeniowe - roczników było więcej niż (przetrzebionych przez wojnę) roczników odchodzących na emerytury i renty. Uzupełnieniem tego źródła były rosnące podatki.

Ten wzrost podatków wyraźnie przyspieszył w dwóch następnych dziesięcioleciach, kiedy to lewicowy ferwor silnie dotknął większość krajów zachodnich. W skali OECD udział wydatków publicznych w produkcie krajowym (relacja WP/PKB) wzrósł w każdej dekadzie o około 8 pkt procentowych, a w skali Europy Zachodniej te przyrosty były jeszcze większe. Podatki, rzecz jasna, rosły w podobnym tempie.

Coś jednak zaczęło zmieniać się pod koniec lat 70. XX w. Coraz wyraźniejsze było niezadowolenie ze wzrostu podatków, niestabilności wzrostu gospodarczego i rosnącej inflacji. Jednocześnie następował intelektualny powrót do klasycznej ekonomii, wzmocnionej nowymi nurtami ekonomii neoinstytucjonalnej (teorii praw własności, teorii ekonomicznej analizy polityki, logiki działań zbiorowych i in.). Efektem zmian politycznych i intelektualnych był wybór takich wolnorynkowych polityków, jak Margaret Thatcher w Wielkiej Brytanii i Ronalda Reagana w Stanach Zjednoczonych.

Ta liberalna kontrrewolucja ,odsztywniła” w pewnym stopniu niektóre gospodarki zachodnie, przyspieszyła nieco ich wzrost gospodarczy i przyczyniła się do wzrostu nastrojów niechętnych dalszym podwyżkom podatków. Jednakże znaczna część podatników, sprzeciwiająca się dalszym podwyżkom podatków, nadal domagała się wzrostu rozmaitych świadczeń społecznych. Jak to stwierdził ze smutkiem politolog z Kalifornii, Aaron Wildavsky, „dostrzegliśmy nieprzyjaciela - i okazaliśmy się nim my sami”.

Politycy dostrzegli owe rozdwojenie jaźni części, a nierzadko większości elektoratu i zaczęli szukać nowych sposobów przypodobania się wyborcom. Wcześniej już, od późnych lat 70. XX w., dostrzegli jeden jeszcze sposób, niewymagający podnoszenia podatków i sprawiający wśród wyborców wrażenie otrzymania czegoś za nic. Były to regulacje zastępujące podatki jako instrument podnoszenia poziomu materialnego komfortu wyborców.

Regulacje więc podnosiły co jakiś czas na wyższy poziom płacę minimalną, zwiększały liczbę dni wolnych od pracy (świąt i urlopów), a także skracały tydzień pracy. Koszty tych regulacji nie musiały być ponoszone przez budżet, z wyjątkiem kosztów dotyczących pracowników sektora publicznego. Ponosili je pracodawcy. Ale, jak to przez lata podkreślał noblista Milton Friedman, nie istnieje obiad za darmo. Ktoś za niego musi zapłacić i tym kimś nie byli tylko pracodawcy. Pracobiorcy aktualni i potencjalni płacili również za tę hojność z cudzych kieszeni utrata pracy lub - częściej jeszcze - dłuższym okresem bezowocnego poszukiwania pracy, gdyż wyższe koszty przerzucone na pracodawców przekładały się na wyższe ceny produktów i usług, a w efekcie na niższy popyt i niższe zatrudnienie. 
Skala prób przypodobania się elektoratowi via regulacje jednakże nie wystarczała. Ponadto niepracująca część elektoratu niewiele mogła na tych regulacjach skorzystać. Zaczął się więc okres zwiększania wydatków publicznych bez ekwiwalentnych przyrostów dochodów. I po jednej, i po drugiej stronie na tę nierównowagę wpływały niekorzystne relacje pracujących do emerytów. Oczywiście politycy mogliby przyjąć zasadę zmniejszania dynamiki wzrostu wydatków publicznych lub nawet powolnej ich stabilizacji i redukcji. Ale przeczyłoby to przyjętym wzorcom zachowań polityków, ugruntowanych w latach 60. XX w. Trudno powiedzieć, czy liczyli oni na jakieś nadzwyczajne efekty prowadzonych polityk; raczej odkładali trudne decyzje na później, gdy o ich podjęciu myśleć będą ich następcy. Zaciąganie długu u przyszłych pokoleń, które płacić miały za dzisiejsze wydatki socjalne państwa i dzisiejsze zobowiązania wobec jutrzejszych emerytów, stało się typowym zjawiskiem w większości krajów zachodnich. Deficyty budżetowe ostatecznie przestały być zjawiskiem charakterystycznym dla fazy recesji w cyklu koniunkturalnym.

Ta era finansowania wydatków socjalnych z deficytu trwała niezmiennie do wybuchu w 2007 r. ,wielkiego kryzysu finansowego”. W folklorze politycznym świata zachodniego ów kryzys miał być jakimś zdarzeniem szczególnym, jakąś katastrofą spowodowaną przez zachłanne ciemne siły międzynarodowych finansów, podczas gdy de facto był w świecie zachodnim jedynie kontynuacja finansowania działań o charakterze socjalnym z deficytów budżetowych. Zmieniła się jedynie skala tych deficytów. Zaczęło się „,wielkie zadłużanie". A oto kilka przykładów tego, jak szybko od 2006 (ostatniego roku przed kryzysem) do 2010 r. rosła relacja wydatków publicznych do PKB:

- w USA relacja wzrosła z 36,0 do $42,3 \%$,

- w Wielkiej Brytanii wzrosła z 44,3 do 51,0\%,

- we Francji wzrosła z 52,7 do 56,2\%,

- w Hiszpanii wzrosła z 38 do $45 \%$

- w Portugalii wzrosła z 44,5 do 50,7\% a

- w Grecji wzrosła z 45,2 do 52,9\% (w 2009 r.).

Uwaga polityków, finansistów i analityków koncentruje się zwykle na skali deficytów budżetowych i na relacji długu publicznego do PKB. Ale - jak podkreślałem w części pierwszej - to właśnie rosnąca relacja wydatków publicznych do PKB jest czynnikiem redukującym bodźce do pracy, zarabiania, oszczędzania i inwestowania i to ona powoduje spadek dynamiki wzrostu gospodarczego.

Ekonomistów zajmujących się ,wielkim zadłużaniem” w ciagu ostatnich kilku lat nurtowało pytanie, kiedy kraje zadłużające się odczuja jego efekty. Bernhard Heitger negatywne efekty rosnącej relacji WP/PKB mierzył w dekadach (zob. pkt I). Inni analitycy również odnosili swoje rozważania do długiego okresu. Trudno $\mathrm{w}$ tych warunkach określić skalę i trwałość negatywnych efektów obecnego bardzo szybkiego wzrostu relacji WP/PKB. Jednouważam - wydaje się pewne: skutki te moga być nieco większe lub nieco mniejsze niż skutki wzrostu tej relacji o 10 punktów procentowych w okresie dekady, ale będą na pewno negatywne. Stawiając kropkę nad „i”, dodam, że przyczyny ,wielkiego zadłużania” sa te same, co w poprzednich dekadach, to znaczy postrzegane potrzeby finansowania państwa opiekuńczego w warunkach głębokiej recesji. 
Alarmujące komentarze słyszane w ostatnich miesiącach o nadchodzącej „,recesji z podwójnym dnem” (double dip recession) wynikaja jednak z niezrozumienia istoty sytuacji, a przede wszystkim przyczyn długookresowego kryzysu. Kraje zachodnie wyszły już z recesji i ich wzrost gospodarczy utrzymuje się - jak to wyżej podkreśliłem - na poziomie 1,0-1,5\%, czyli nowej normy.

Ma to poważne następstwa, gdyż zamyka politykom drogę do ,ucieczki z zadłużenia" przez stymulację makroekonomiczną. Wiele wskazuje na to, że politycy nie maja już więcej królików, które - w celu kontynuacji finansowania państwa opiekuńczego - mogliby jeszcze wyciagnąc z coraz bardziej wyświechtanego cylindra. Nieprzyjemna arytmetyka fiskalna - by sparafrazować najnowszego noblistę z ekonomii - zmusi ich w najbliższych kilku latach do zmierzenia się $\mathrm{z}$ rzeczywistością, czyli $\mathrm{z}$ koniecznością cięcia wydatków socjalnych.

Niedawne głośne studium reform zmierzających do stabilności makroekonomicznej wskazuje dowodnie, jak takie reformy powinny być realizowane. Alberto Alesina i Silvia Ardagna przeanalizowali 107 przypadków reform stabilizacyjnych i stwierdzili, że skuteczne reformy charakteryzowały się tym, że $85 \%$ wartości zmniejszania luki między dochodami a wydatkami pochodziło z cięć wydatków, a tylko $15 \%$ ze zmian podatków (niekoniecznie zresztą ze zwiększenia podatków!). Połączenie badań nad negatywnymi skutkami rosnacych relacji WE/PKB oraz wzmiankowane badania Alesiny i Ardagny wskazuja na odpowiedź, dlaczego tradycyjna keynesowska stymulacja nie skutkuje.

Podkreślana parokrotnie struktura bodźców, która coraz mniej zachęca do pracy, zarabiania, oszczędzania i inwestowania, łączy się $\mathrm{w}$ obecnych warunkach z niskim tempem wzrostu gospodarczego i wysokim poziomem niepewności. Ten ostatni wynika między innymi z już wysokich podatków i groźby ich zwiększenia (według populistycznych, podszytych zawiścią haseł: „Niech bogaci zapłaca!”). A to, rzecz oczywista, zniechęca ludzi szczególnie uzdolnionych do tworzenia bogactwa, aby zatrudniali i produkowali, nie mówiąc już o inwestowaniu.

\section{Dodatkowe ciężary państwa opiekuńczego i „państwa szalejacego”}

Dotychczasowe rozważania traktowały wzrost wydatków państwa opiekuńczego w sposób niezróżnicowany i niezmienny. Tymczasem mniej więcej od połowy lat 90 . XX w. coraz silniej zaczęły na wydatkach ogółem ważyć wydatki emerytalne. Ciąża one na krajach zachodnich po obu stronach Atlantyku, chociaż sytuacja demograficzna Europy wygląda znacznie gorzej. Tymczasem poziom obecnych świadczeń emerytalnych jest już przemożnym ciężarem, a jeśli brać pod uwage szybko pogarszające się w Europie relacje demograficzne, to poziom przyszłych, już przyobiecanych świadczeń jest po prostu nierealizowalny. Prezes związku banków niemieckich, Andreas Schmitz, stwierdził niedawno (,Financial Times” z 17 października 2011 r.), że obecne demonstracje przeciwko bankom ,sa odwracaniem uwagi od fundamentalnego problemu: nie jesteśmy w stanie dłużej finansować naszego państwa opiekuńczego [w jego obecnym wymiarze - J.W.]". 
Trzeba przyznać, że w niektórych krajach europejskich podejmowane sa pewne ważne kroki, które moga $\mathrm{w}$ jakiejś mierze poprawić sytuację. $\mathrm{Na}$ przykład w Niemczech uchwalono podwyższenie wieku przechodzenia na emeryturę mężczyzn i kobiet do 67 roku życia. Poprawiać to będzie stopniowo (proces rozłożony jest na lata) proporcje zatrudnionych do emerytów. Obok Niemiec podobne kroki podjęły też niektóre inne kraje europejskie.

Silniejszym środkiem zaradczym byłoby przyspieszenie wzrostu gospodarczego. To akurat wydaje się jednak niemożliwe bez:

a) znaczącego zredukowania poziomu wydatków państwa opiekuńczego ( $\mathrm{z}$ obniżeniem poziomu emerytur jako najważniejszym komponentem cięć),

b) utrzymania tego zredukowanego poziomu przez kilka lat, co umocniłoby wiarygodność polityki.

Dopiero po kilku latach, gdy pracodawcy i pracobiorcy przekonaliby się już, że zmniejszone obciążenia podatkowe trwale zachęcają do pracy, zarabiania, oszczędzania i inwestowania, można by liczyć na pozytywne reakcje z ich strony - i w efekcie na wyższe tempo wzrostu gospodarczego. Długość tego opóźnienia byłaby zapewne różna w przypadku poszczególnych krajów, w zależności od poziomu wiarygodności prowadzonej wcześniej polityki.

Doświadczenia ostatnich lat wskazują jednak, iż zmierzenie się z rzeczywistością będzie bardzo trudne. Wystarczy przypomnieć gwałtowne protesty we Francji $\mathrm{w}$ związku $\mathrm{z}$ bagatelnym $\mathrm{w}$ gruncie rzeczy podniesieniem wieku emerytalnego z 60 do 62 lat albo protesty Greków, Hiszpanów czy Anglików zarówno starych, jak i młodych. Niemniej, ponieważ nie ma już kolejnych królików w zdezelowanym cylindrze polityków, takie zmierzenie się z rzeczywistością jest nieuchronne w nieodległej przyszłości.

Ale nie koniec na tym. W tejże samej nieodległej przyszłości Zachód ponosić będzie bardzo znaczne koszty prowadzonej polityki energetycznej opartej na złudnym założeniu, że jest rzeczą możliwą do zrealizowania wyeliminowanie w okresie 2-3 dziesięcioleci paliw kopalnych (węgla, ropy i gazu ziemnego). A wszystko to w celu walki ze spowodowanym jakoby przez człowieka globalnym ociepleniem (anthropogenic global warming).

Jest to specyficznie zachodnie zjawisko, które inni generalnie traktuja jako rzecz niewarta zaangażowania. Dlatego zabawy w rodzaju protokołu z Kioto przyjęte zostały głównie przez Europejczyków (Ameryka uczyniła ten krok dopiero niedawno, za obecnej administracji prezydenta Obamy). A emisja gazów cieplarnianych w okresie obowiązywania wzmiankowanego protokołu zwiększyła się o prawie 30\%. Mimo wyraźnego braku zainteresowania ze strony innych państw, Unia Europejska nie ustaje w wymyślaniu kolejnych reguł mających redukować dwutlenek węgla, obciążając kosztami producentów i użytowników energii. Koszty tego przedsięwzięcia - gdyby zostało ono wprowadzone w życie i egzekwowane zgodnie z przyjętymi i planowanymi regulacjami byłyby nie tylko gigantyczne, ale podważyłyby radykalnie podstawy konkurencyjności sporej części europejskiego przemysłu.

Trudno nie zastanawiać się nad przyczynami takiego „odruchu lemingów” w i tak już przecież coraz słabiej funkcjonującej Europie. Szaleństwa regulacyjne w słabnącej Europie i Ameryce muszą więc mieć jakąś mocna podbudowę (najlepiej w sferze innej niż wiedza ekonomiczna!). Ekonomista 
i filozof Deepak Lal z Uniwersytetu Kalifornijskiego w Los Angeles uważa, iż sekularyzujący się Zachód znalazł w ekologii swoistą świecką religię ${ }^{6}$. Skoro ludzie przestali wierzyć w chrześcijańskiego Boga, który troszczy się i o przyrodę, i o człowieka, to człowiek sam musi przejąć tę troskę o stan przyrody.

W tej materii mam inną koncepcję. Uważam, że przyczyn pojawienia się tej świeckiej religii szukać należy nie tyle w zeświecczeniu Zachodu, ile w utrzymującym się $\mathrm{m}$ i m o wiary religijnej, lub jej odrzucenia, popperowskim „,ciśnieniu (pre)historii”. Tyle że Karl Popper tłumaczył ciśnieniem prehistorii ludzkie instynktowne preferencje dla systemów kolektywistycznych. Ludzie bowiem w grupach łowiecko-zbierackich, czy później w rolniczych wspólnotach, z konieczności szukali przetrwania w (niewielkich) społecznościach, w których system wzajemnej kontroli utrzymywał wysoki poziom zaangażowania wszystkich członków w sprawy grupy.

Popperowskie spojrzenie na instynktowne, a nie racjonalne, kolektywistyczne preferencje skłonny jestem rozszerzyć na stosunek jednostki do przyrody od czasów najdawniejszych. Ludzie żyli w strachu przed przyrodą i jej rozlicznymi, niezrozumiałymi dla nich przejawami. I ubóstwiali to, czego tak bardzo się bali. Nie jest zaskoczeniem, że w wielu prymitywnych religiach mieliśmy boga piorunów i jemu podobnych.

Ten głęboko zakorzeniony strach w wielu umysłach zachował się do naszych czasów. Ludzie obawiają się wszystkiego, co nie znajduje się w przyrodzie $\mathrm{w}$ takim stanie, w jakim jest ono następnie użytkowane przez człowieka. Stąd powtarzający się strach i histeryczne apele o wycofanie się z produkcji jakichś substancji. Dlatego znajdujący się pod psychologicznym ciśnieniem prehistorii ekolodzy najczęściej wojują z chemia, ale także z transformacją paliw i wieloma innymi procesami technologicznymi i efektami tych procesów.

Taką mentalność, którą w jednym z artykułów publicystycznych nazwałem postnaukowym ciemnogrodem, można by traktować jako swoiste społeczne kuriozum. Jednakże ekologom udało się owymi strachami zakazić umysły milionów. Wiemy już, jakie sa podstawy psychologiczne tego sukcesu; strach przed przyroda, jeśli dopuści się do jej skażenia, do pojawienia się czegoś, czego przedtem $\mathrm{w}$ takiej postaci nie było, wynikający z owego ciśnienia prehistorii. Strach przed nadmiarem gazów cieplarnianych jest nieodłączną częścią takich reakcji. Ale warto się zastanowić, dlaczego ekologom - czy ekowojownikom udało się to, co nie udało się innym ekstremistom. Samo poparcie milionów ludzi nie wystarcza, czego dowodzi historia wielu ruchów masowych.

Na przykład millenaryści, gdy zbliżał się rok 1000 n.e., który uznali za rok końca świata i sądu ostatecznego, nie przekonali większości do samobiczowania się ani tym bardziej nie zmusili innych do gwałtownej formy ekspiacji. Otóż millenaryści nie mieli dwóch potężnych sojuszników, jakimi są media i politycy.

Media wspierają straszących końcem świata $\mathrm{z}$ tego czy innego powodu ekologów (a powodów ekolodzy są zdolni wymyślić niemało!), katastrofy bowiem są medialnie atrakcyjne - zwiększaja nakłady prasy i oglądalność lub słuchalność mediów elektronicznych.

${ }^{6}$ Zob. jego The Unintended Consequences, Blackwell, Oxford 1998. 
Politycy mają również silne bodźce do wspierania ekologów. Są one dwojakie:

- pierwszy powód, to próżność. Politycy chcą być podziwiani i wyobrażają siebie jako rycerzy w lśniącej zbroi przybywających na ratunek zagrożonemu przez globalne ocieplenie elektoratowi;

- drugi powód jest znacznie bardziej przyziemny - pieniądze, a najlepiej wyjaśnia to teoria public choice. Politycy wygrywają wybory najczęściej wtedy, gdy dzielą pieniądze. Otóż nadmiar już przyznanego socjalu i niedostatek źródeł jego finansowania powodują, że politykom brakuje od dawna nowych pieniędzy, za pomoca których mogliby się podmaślać elektoratowi. „Walka z globalnym ociepleniem", która zabiera w postaci podatków i opłat pieniądze firmom produkującym energię z paliw kopalnych (emitujących $\mathrm{CO}_{2}$ ) oraz tej energii użytkownikom, pozwala politykom subsydiować różne przedsięwzięcia z zakresu tak zwanych odnawialnych źródeł energii, zyskując sobie wdzięcznych stronników (to zaś, że owe odnawialne źródła najczęściej nie maja uzasadnienia ekonomicznego, obchodzi ich już znacznie mniej).

W ten sposób ekologom udało się zawładnąć wyobraźnią (czytaj: strachem) milionów ludzi w świecie zachodnim i racjonalna argumentacja okazuje się trudna do przebicia, zwłaszcza że Komisja Europejska - odcinana coraz bardziej od kluczowych decyzji w kwestiach związanych z kryzysem - szuka dla siebie miejsca i produkuje coraz dalej sięgające $\mathrm{w}$ przyszłość kuriozalne plany i dyrektywy.

Jestem jednak przekonany, że autentyczny kryzys państwa opiekuńczego musi - przez sam fakt koniecznej koncentracji na sprawach najważniejszychprzywrócić właściwą hierarchię ważności różnym kategoriom wydatków publicznych. To, co mniej pilne, musi ustąpić temu, co najpilniejsze. To, co jedynie prawdopodobne, musi ustąić temu, co realne. Konieczność przywracania równowagi dochodów i wydatków państwa opiekuńczego już wymusza inne spojrzenie na wydatki pozostałe. Dotyczy to również szaleństwa „ociepleniowego”. Jeden kraj po drugim w Europie tnie rozmaite subsydia dla tak zwanej energii odnawialnej. Najbardziej jednoznacznie wypowiedział się $\mathrm{w}$ tej kwestii premier Holandii, Mark Rutte. Z typową dla Holendrów bezpośredniością stwierdził, że okazało się, iż wiatraki napędzane są nie wiatrem, a subsydiami i w budżecie na rok następny zaproponował zmniejszenie wydatków budżetowych na energię odnawialną z 4 do 1,5 mld euro.

Pozwala to spojrzeć na sprawę kosztów ,walki z globalnym ociepleniem” z nieco innej perspektywy. W warunkach imperatywu redukcji wydatków publicznych i priorytetu dla utrzymania minimum państwa opiekuńczego, inne wydatki - w tym wydatki, o których mowa - będą podlegać kolejnym ograniczeniom. Nie nastąpi więc odcięcie się polityków od „ociepleniowych” utopii, niemniej z upływem lat projekt ten zemrze śmiercią naturalną przez zagłodzenie i zapomnienie. Zagłodzenie $\mathrm{w}$ sensie malejących wydatków subsydiujących czeka różne energetyczne idee niemające zdrowych fundamentów ekonomicznych, czyli niemal wszystkie. Zapomnienie w tym sensie, że redukowanie subsydiów i wymuszane przez kręgi gospodarcze łagodzenie różnych wielce kosztownych regulacji zmarginalizuje cały ten projekt $\mathrm{w}$ obecnej, a najdalej następnej dekadzie. 


\section{POST SCRIPTUM}

Podsumowując powyższe rozważania, należy stwierdzić, że nie tylko strefę euro, nie tylko Europę, lecz Zachód jako całość czekają kosztowne i bolesne dostosowania. Tylko te kraje, które już zaczęły lub zaczną podejmować w najbliższych latach ważne kroki w celu przezwyciężenia kryzysu państwa opiekuńczego, będą w stanie uniknąc stagnacji i wręcz trwałego spadku PKB. I te właśnie kraje będą $\mathrm{w}$ stanie zachować państwo opiekuńcze $\mathrm{w}$ jego zasadniczych elementach (jak to czyni na przykład Szwecja pod rządami liberalno-konserwatywnymi, deregulując i tnąc wydatki socjalne). Powrót do szybszego wzrostu gospodarczego wymaga społecznej akceptacji tego, co oczywiste i nieuchronne; a do tego jeszcze długa, kilkuletnia zapewne, droga...

dr hab. Jan Winiecki

Profesor Wyższej Szkoty Informatyki i Zarzadzania w Rzeszowie

\section{CRISIS OF THE EUROZONE AND ITS ORIGIN}

\section{Summary}

The author identifies the less often discussed institutional and policy issues of the Eurozone. He points out the theory-inconsistent creation of the monetary union performed ahead of the economic and fiscal union, the implementation of surrogate solutions such as the Growth and Stability Pact and the weak discipline in its observance, as well as the surprising lack of exit rules and the real problem of the crisis that is not financial, but that of waning confidence. He further warns that the Eurozone crisis, serious as it is, is an outgrowth of a much more serious and lasting problem of the crumbling Western welfare state and its ever growing size of indebtedness. The financial crisis has simply accelerated the day of reckoning by a few years, but without major changes the collapse is inevitable. The kind of changes needed is politically costly and, therefore, will be introduced only when all other non-solutions have failed. For that reason the author expects that the crisis of the West will last for at least another 5-10 years. 